Pathobiochemistry

\title{
Biliary and hepatic metallothionein, metals and trace elements in environmentally exposed neotropical cichlids Geophagus brasiliensis
}

\author{
Sylvia N. Land ${ }^{\mathrm{a}}$, Rafael Christian C. Rocha ${ }^{\mathrm{b}}$, Isabella C. Bordon ${ }^{\mathrm{c}}$, Tatiana D. Saint'Pierre ${ }^{\mathrm{b}}$, \\ Roberta L. Ziolli ${ }^{\mathrm{a}}$, Rachel A. Hauser-Davis ${ }^{\mathrm{d}, *}$

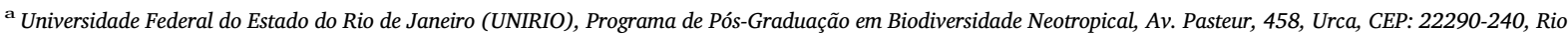 \\ de Janeiro, RJ, Brazil \\ ${ }^{\mathrm{b}}$ Pontifícia Universidade Católica do Rio de Janeiro (PUC-Rio), Departamento de Química, Rua Marquês de São Vicente, 225, Gávea, CEP: 22453-900, Rio de Janeiro, \\ RJ, Brazil \\ ${ }^{\mathrm{c}}$ Universidade do Estado de São Paulo (UNESP), Campus do Litoral Paulista, Praça Infante Dom Henrique, s/no, Parque Bitaru, CEP: 11330-900, São Vicente, São Paulo, \\ SP, Brazil \\ d Fundação Oswaldo Cruz (Fiocruz), Centro de Estudos da Saúde do Trabalhador e Ecologia Humana, Escola Nacional de Saúde Pública Sérgio Arouca, Rua Leopoldo \\ Bulhões, 1480, CEP: 21040-900, Manguinhos, Rio de Janeiro, RJ, Brazil
}

\section{A R T I C L E I N F O}

\section{Keywords:}

Metals

Metallothionein

Detoxification

Metal molar ratios

Risk assessment

Public health

\begin{abstract}
A B S T R A C T
One of the metal detoxifying mechanisms that occurs in fish is metallothionein (MT) induction and metal binding. Hepatic MT induction has been well described, but biliary MT metal detoxification has only recently been described in fish. In this scenario, metal-metal interactions have been increasingly evaluated to further understand the behavior of these contaminants regarding homeostasis and biological functions, as well as their toxic effects. Studies, however, have been mainly conducted concerning the elemental pair Se-Hg, and scarce reports are available concerning other metal pairs. Therefore, this study aimed to evaluate biliary and hepatic MT metal detoxification mechanisms in a territorial neotropical cichlid, Geophagus brasiliensis. Fish were sampled from the anthropogenically impacted estuarine Rodrigo de Freitas Lagoon, located in Southern Rio de Janeiro, and trace elements and MT were determined by inductively coupled plasma mass spectrometry (ICP-MS) and UV-Vis spectrophotometry, respectively, in fish liver and bile. MT in bile were significantly lower than in liver. Significant differences between bile and liver were observed for many trace elements, and, although most were higher in liver, Cd and Ni were significantly higher in bile, indicating efficient excretion from the body via the biliary route. A significant correlation was observed between MT and Fe in bile, and between MT in liver and Cu and $\mathrm{Zn}$ in bile. Molar ratio calculations demonstrated protective elements effects against $\mathrm{Al}, \mathrm{As}, \mathrm{Cd}, \mathrm{Hg}, \mathrm{Pb}$ and $\mathrm{V}$ in both bile and liver, as well as some novel interrelationships, indicating the importance of these investigations regarding the elucidation of element detoxifying mechanisms. Furthermore, investigation of other elemental associations may aid in decision-making processes regarding environmental contamination scenarios linked to public health.
\end{abstract}

\section{Introduction}

Aquatic environmental pollution by metals and trace-elements has become a worldwide problem, since these compounds show potential toxic effects and can bioaccumulate in aquatic ecosystems [1]. To counteract the negative effects caused by the presence of toxic elements or essential elements in excess, organisms present certain biochemical defenses, such as increased metallothionein (MT) synthesis, that binds to free elements [2]. MT have been implicated in the homeostasis of essential elements, such as $\mathrm{Cu}$ and $\mathrm{Zn}$, as well as in the detoxification of toxic metals, such as $\mathrm{Ag}, \mathrm{Cd}, \mathrm{Pb}$ and $\mathrm{Hg}$ [3], although this metalloprotein has also displayed protective free radical scavenging activity, playing an active role in the capture of harmful oxidant species [4], both capabilities due to abundant cysteine residues. Because of these properties, MT are considered adequate biomarkers for metal and traceelement exposure, and have been increasingly applied to detect oxidative stress.

Recently, biliary fish MT have been shown to follow the same trend as hepatic MT, demonstrating an alternative detoxifying mechanism for metals and trace-elements [5]. In addition, fish bile has also been

\footnotetext{
* Corresponding author.

E-mail address: rachel.hauser.davis@gmail.com (R.A. Hauser-Davis).
} 
validated as a biomarker for metal and trace-element excretion, and certain elements have been reported as excreted preferentially by this route, before reaching a certain threshold and accumulating in the liver [6]. However, studies in this regard are scarce, and many variables in this process are still unknown. Thus, further analyses are required to better investigate this detoxification route.

Elemental interactions in living organisms may lead to different effects, by inducing synergistic (increased), antagonistic (decreased) or additive (independent) behavior [7], depending on element bioavailability, uptake from the environment and different distribution patterns in fish tissues [8]. Because of this, interactive effects of elemental pairs have been increasingly evaluated in both in vivo and in vitro studies, in the laboratory or in the field, and contribute to further understanding of the behavior of these contaminants both in homeostasis and biological functions and concerning toxic effects. Studies in this regard, however, have been mainly conducted concerning the Se-Hg pair, and not many reports are available concerning other elemental pairs. In addition, to the best of our knowledge, no studies in this regard have been conducted in bile.

In this context, the aim of the present study was to characterize biliary and hepatic metallothionein-mediated element detoxification mechanisms and interactions of both essential and non-essential metals and trace-elements by metallothioneins in environmentally exposed territorial neotropical cichlids Geophagus brasiliensis.

\section{Methodology}

\subsection{Study area}

The estuarine ecosystem of the Rodrigo de Freitas Lagoon is located in the highly urbanized south region of Rio de Janeiro $\left(22^{\circ} 5700200 S\right.$; $043^{\circ} 1100900 \mathrm{~W}$ ), southeastern Brazil (Fig. 1). It is connected to the sea by a narrow channel, although this channel is frequently blocked by sand deposits and, thus, does not allow for free water exchanges, restricting circulation and water renewal [9]. Because of this, water stratification occurs, with the deeper water layer frequently becoming anaerobic and rich in hydrogen sulfide $\left(\mathrm{H}_{2} \mathrm{~S}\right)$ gas, due to oxidation of the organic matter present in the bottom of the lagoon. This, in turn, results in low water quality level, leading to many episodes of low dissolved oxygen levels, anoxic conditions and frequent fish mortality [10]. These characteristics present favorable conditions for pollutant accumulation in the lagoon's substratum. In addition, the lagoon illegally receives untreated domestic sewage enriched in organic matter, detergents, synthetic organic material and metals and trace-elements on a daily basis, and is also exposed to huge hydrocarbon and metal and trace-elements inputs originated from incomplete combustion of fossil fuels, due to the approximately 190 thousand vehicles that pass through the area each day [11], as well as the presence of several surrounding gas stations [9].
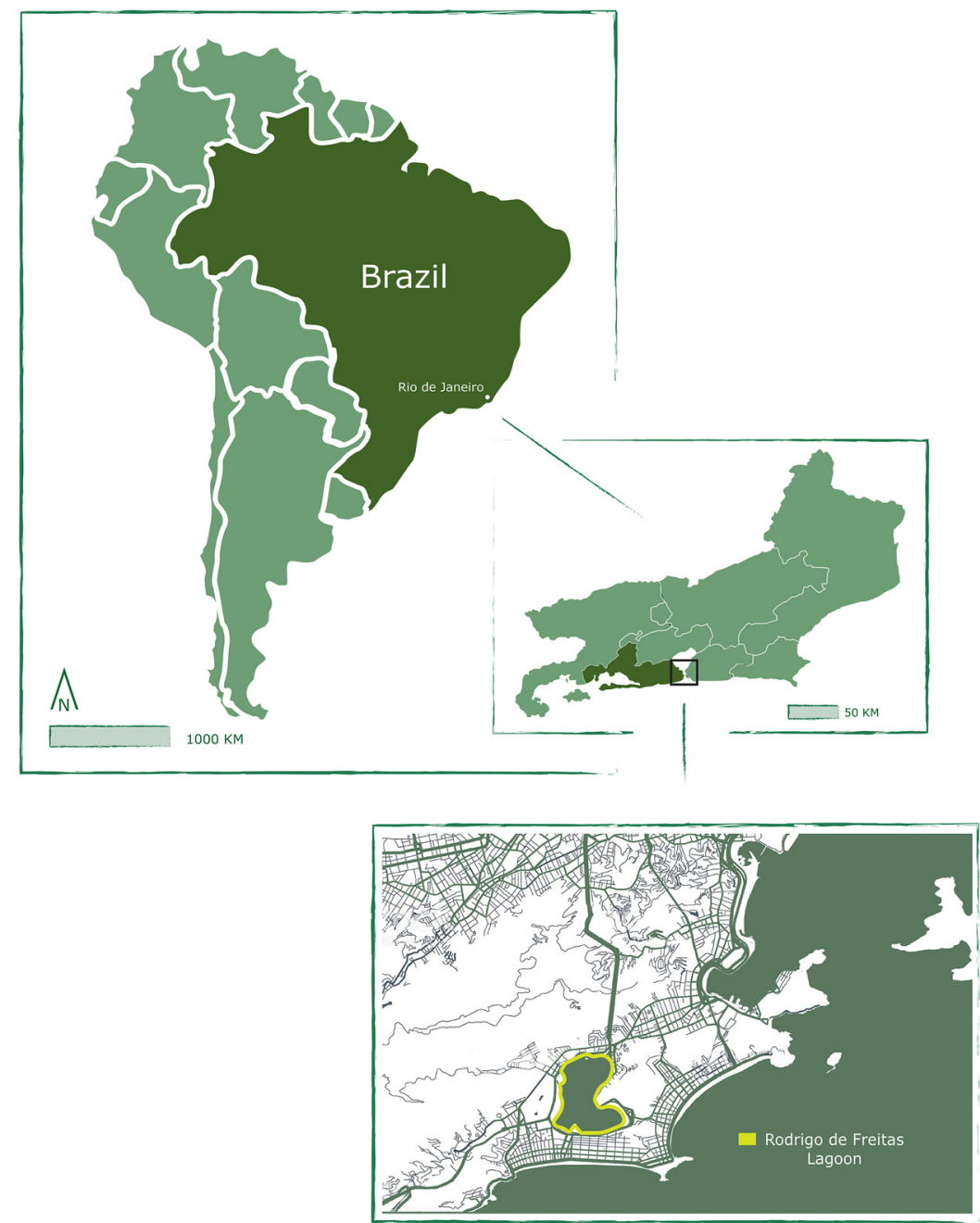

Fig. 1. Map of the study area, with the Rodrigo de Freitas Lagoon displayed in the inlay, located in Southeastern Brazil. 


\subsection{Sampling}

Adult $G$. brasiliensis specimens $(\mathrm{n}=17)$ were sampled from the Rodrigo de Freitas Lagoon by local fishermen and maintained alive in underwater cages until taken to the laboratory (time between capture and transport was no longer than $1 \mathrm{~h} 30 \mathrm{~min}$ ). This species was chosen because it is considered an adequate sentinel species regarding environmental monitoring, since it is non-migratory, territorial and limnobenthofagous, and, therefore, particularly exposed to sediment-associated contamination, such as metals and trace-elements [12].

At the laboratory, fish were quickly sacrificed by spinal cord severing. After weighing and measuring each individual, bile was collected by direct puncture of the gallbladder with a disposable syringe, and livers were dissected, removed and weighed. Bile samples were immediately aliquoted and stored at $-80 \circ \mathrm{C}$ in sterile eppendorfs, while liver samples were freeze-dried for 48 h (Liotop 101, Liobrás, São Paulo, Brazil) and powdered with mortar and pestle.

\subsection{MT purification and determination}

MT purification was carried out by taking advantage of the heatstable properties of these metalloproteins. Briefly, liver and bile samples (approximately $100 \mathrm{mg}$ aliquots) were homogenized in a buffer solution (Tris $-\mathrm{HCl} 20 \mathrm{mmol} \mathrm{L} \mathrm{L}^{-1}$, pH 8.6 containing phenylmethylsulphonylfluoride at $0.5 \mathrm{mmol} \mathrm{\textrm {L } ^ { - 1 }}$ as an antiproteolytic agent and $\beta$-mercaptoethanol $0.01 \%(\mathrm{w} / \mathrm{v}))$ as a reducing agent, and centrifuged at 20,000 x $g$ for $1 \mathrm{~h}$ at $4{ }^{\circ} \mathrm{C}$ in a Mikro 220R refrigerated centrifuge (Hettich, Germany). The supernatants were then heated at $70{ }^{\circ} \mathrm{C}$ for $10 \mathrm{~min}$, to denature most proteins, centrifuged again in the same conditions for $30 \mathrm{~min}$ to precipitate the denatured proteins, and then collected and frozen at $-80{ }^{\circ} \mathrm{C}$ [13]. MT quantification in the purified supernatants followed the protocol reported by Viarengo et al. [14], with modifications, where samples are homogenized in a buffer solution $\left(1 \mathrm{~mol} \mathrm{~L}^{-1} \mathrm{HCl}, 4 \mathrm{~mol} \mathrm{~L}^{-1}\right.$ EDTA, $2 \mathrm{~mol} \mathrm{~L}^{-1} \mathrm{NaCl}, 0.43 \mathrm{~mol}$ $\mathrm{L}^{-1}$ DTNB in a $0.2 \mathrm{~mol} \mathrm{~L}^{-1} \mathrm{Na}_{2} \mathrm{PO}_{4}, \mathrm{pH} 8.0$ ), incubated for $30 \mathrm{~min}$ to form a colored solution [15] and then analyzed by UV-vis spectrophotometry at $412 \mathrm{~nm}$, carried out using a Perkin Elmer Lambda 35 spectrophotometer. MT concentrations were estimated using GSH as an external standard by applying an equivalence ratio of $20 \mathrm{~mol} \mathrm{GSH}: 1 \mathrm{~mol}$ MT [16].

\subsection{Metal and trace-element determinations}

Approximately $250 \mathrm{mg}$ of each sample (liver in powdered form and bile in liquid form) were weighed in $15 \mathrm{ml}$ screw-capped polypropylene tubes. Concentrated subboiled bidistilled nitric acid (Vetec, Rio de Janeiro) was added to each sample $(1.5 \mathrm{~mL})$ and the mixtures were left to stand, closed, overnight at room temperature. The following day, the acid digestions were completed by heating the samples at $100^{\circ} \mathrm{C}$, for approximately $4 \mathrm{~h}$ in the closed vessels, to avoid volatilization of certain elements, such as $\mathrm{Hg}$ and Se. Samples were then diluted with ultra-pure water (resistivity $>18.0 \mathrm{M} \Omega \mathrm{cm}$ ) to $10 \mathrm{~mL}$. Metals and trace-elements (Al, V, Cr, Fe, Co, Ni, Cu, Zn, As, Se, Cd, $\mathrm{Hg}$ and $\mathrm{Pb}$ ) were determined, in triplicate, using multielemental external calibration, by appropriate dilutions of a mixed standard solution (Merck IV). The determinations were conducted on an ELAN DRC II ICP-MS (Perkin-Elmer Sciex, Norwalk, CT, USA), using ${ }^{103} \mathrm{Rh}$ as an internal standard, at $20 \mathrm{mg} \mathrm{L}^{-1}$. Method accuracy was verified with procedural blanks and by the parallel analysis of DORM-4 (dogfish muscle tissue) certified reference material (National Research Council of Canada), in triplicate. Table 1 displays the observed and certified values for the DORM-4 certified reference material (in $\mathrm{mg} \mathrm{kg}^{-1} \mathrm{dry}$ weight), their recoveries (\%) and the LODs (in $\mathrm{mg} \mathrm{kg}^{-1}$ ) for each determined element.
Table 1

Observed and certified values for the DORM-4 certified reference material (in $\mathrm{mg} \mathrm{kg}{ }^{-1}$ dry weight), recoveries (\%) and LODs (in $\mathrm{mg} \mathrm{kg}^{-1}$ ) for each element determined in the present study.

\begin{tabular}{lllll}
\hline & Observed value & Certified Value & Recovery (\%) & LOD \\
\hline Al & $1308 \pm 91.7$ & $1280 \pm 340$ & 102 & 0.05 \\
V & $1.52 \pm 0.14$ & $1.57 \pm 0.14$ & 97 & 0.08 \\
Cr & $1.75 \pm 0.27$ & $1.87 \pm 0.18$ & 94 & 0.05 \\
Fe & $351 \pm 35.3$ & $343 \pm 20$ & 102 & 0.39 \\
Co & $0.25 \pm 0.018$ & 0.25 & 100 & 0.0003 \\
Ni & $1.29 \pm 0.11$ & $1.34 \pm 0.14$ & 96 & 0.004 \\
Cu & $16.3 \pm 0.87$ & $15.7 \pm 0.46$ & 104 & 0.011 \\
Zn & $54.7 \pm 5.65$ & $51.6 \pm 2.8$ & 106 & 0.08 \\
As & $7.03 \pm 0.20$ & $6.87 \pm 0.44$ & 102 & 0.005 \\
Se & $3.63 \pm 0.25$ & $3.45 \pm 0.40$ & 105 & 0.04 \\
$\mathbf{C d}$ & $0.36 \pm 0.025$ & $0.299 \pm 0.018$ & 87 & 0.001 \\
$\mathbf{H g}$ & $0.43 \pm 0.035$ & $0.412 \pm 0.0036$ & 104 & 0.002 \\
$\mathbf{P b}$ & $0.40 \pm 0.13$ & $0.404 \pm 0.062$ & 99 & 0.001 \\
\hline
\end{tabular}

\subsection{Statistical analyses}

All data were normalized by fish length, in order to remove interferences due to differences in size and weight. Thus, parametric tests were subsequently applied. Pearson's correlation test was used to evaluate the degree of associations between the elements themselves and between MT determined in liver and bile, while Student's $t$-test was used to assess the differences between the elemental concentrations in the different organs. The significance level for all statistical tests was set at $\mathrm{p}<0.05$. To elucidate the overall relationship between elements and MT in liver and bile, a Principal Component Analysis (PCA) was carried out, in addition to a Cluster analysis (CA), to further classify the elements into groups representing the different variables (MT and elements) in liver and bile. The variables used in these statistical techniques were standardized by means of Z-scores. Euclidean distances were calculated and Ward's method was performed. A dendrogram was then constructed to assess the cohesiveness of the formed groupings, in which correlations between the elements and MT in the different tissues could be observed. The statistical analyses were performed on the Statistica 7 (StatSoft) and $\mathrm{R}$ version 3.0.2 software packages for Windows.

\section{Results and discussion}

\subsection{MT, metal and trace-element levels in G. brasiliensis bile and liver}

As anticipated, MT levels in bile were significantly lower than liver concentrations (Fig. 2), corroborating previous studies conducted in fish [5]. This is expected, since the liver is the main detoxifying organ of the body and can accumulate high levels of contaminants, whereas only

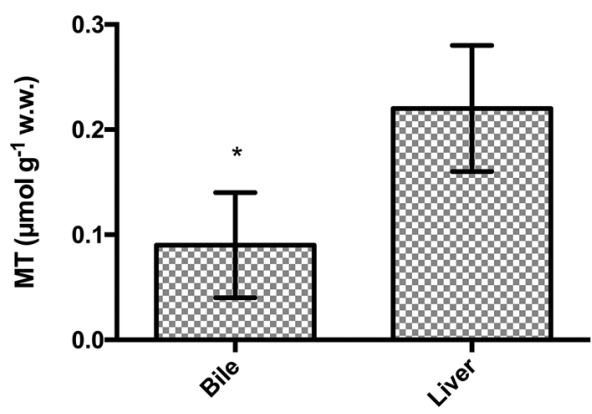

Fig. 2. Biliary and hepatic metallothionein levels in G. brasiliensis sampled from the Rodrigo de Freitas Lagoon, Rio de Janeiro, Brazil. Mean values and standard deviations are presented; $\mathrm{n}=17$. 
excess bile is stored in the gallbladder, in contact with xenobiotics being constantly detoxified by the liver [5,17].

Regarding metal and trace-element levels, significant differences between bile and liver were observed for $\mathrm{Cd}, \mathrm{Fe}, \mathrm{Ni}, \mathrm{Cu}, \mathrm{Zn}, \mathrm{As}$, Se and Hg. Table 2 displays the metal and trace-element concentrations determined in the present study for both liver and bile. Liver data, although obtained from freeze-dried samples, was transformed into wet weight to carry out comparisons with bile, by calculating $70 \%$ water content.

Table 2

Metal and trace-element concentrations in G. brasiliensis bile and liver from the Rodrigo de Freitas Lagoon, Rio de Janeiro, Brazil (data are displayed as means \pm standard deviation, in $\mathrm{mg} \mathrm{L}^{-1}$ wet weight for both liver and bile, $\mathrm{n}=17)$.

\begin{tabular}{lll}
\hline & Bile & Liver \\
\hline Al & $<$ LOD & $2.256 \pm 1.650$ \\
V & $<$ LOD & $0.631 \pm 0.221$ \\
Cr & $0.240 \pm 0.135$ & $0.476 \pm 0.272$ \\
Fe & $11.163 \pm 4.145$ & $539.7 \pm \pm 195.7^{\mathrm{a}}$ \\
$\mathbf{C o}$ & $0.380 \pm 0.235$ & $0.312 \pm 0.122$ \\
$\mathbf{N i}$ & $0.568 \pm 0.337^{\mathrm{a}}$ & $0.104 \pm 0.052$ \\
$\mathbf{C u}$ & $6.166 \pm 1.809$ & $11.15 \pm 6.695^{\mathrm{a}}$ \\
$\mathbf{Z n}$ & $1.299 \pm 1.444$ & $36.11 \pm 7.116^{\mathrm{a}}$ \\
$\mathrm{As}$ & $0.198 \pm 0.058$ & $0.473 \pm 0.098^{\mathrm{a}}$ \\
$\mathrm{Se}$ & $0.425 \pm 0.161$ & $5.308 \pm 1.421^{\mathrm{a}}$ \\
$\mathbf{C d}$ & $0.790 \pm 0.66^{\mathrm{a}}$ & $0.030 \pm 0.023$ \\
$\mathbf{H g}$ & $0.012 \pm 0.010$ & $0.022 \pm 0.005^{\mathrm{a}}$ \\
$\mathbf{P b}$ & $0.978 \pm 0.530$ & $<$ LOD \\
\hline
\end{tabular}

a Indicates statistically significant differences between bile and liver.

$\mathrm{Al}$ and $\mathrm{V}$ were below the LOD in bile, while $\mathrm{Pb}$ was below the LOD in liver. $\mathrm{Fe}, \mathrm{Cu}, \mathrm{Se}, \mathrm{As}, \mathrm{Hg}$ and $\mathrm{Zn}$ were not efficiently removed by the biliary pathway, since concentrations were significantly higher in liver. $\mathrm{Cd}$ and $\mathrm{Ni}$, however, were significantly higher in bile, indicating efficient excretion from the body through this pathway.

Regarding toxic effects to exposed organisms, some studies do not state in which tissue certain toxicity thresholds for aquatic biota are reported, while others state this is specifically in muscle. Thus, we will compare levels reported in the literature for each element with both liver and bile and briefly discuss comparisons with limits reported in the literature. In addition, not all elements have literature-reported values regarding toxicity thresholds in aquatic organisms.

Among those that have been described, Se has been reported as showing adverse effects on aquatic biota in the range of 0.117 to $0.75 \mathrm{mg} \mathrm{kg}^{-1}$ (wet weight) in tissues in general, while As is considered damaging for fish and other aquatic organisms at over $0.09 \mathrm{mg} \mathrm{kg}^{-1}$ wet weight in tissues in general [18-20]. Se in the present study was significantly higher than the level of concern in liver, and in the cited range in bile, while As levels where in the concern range for both organs. As was substantially higher than the average found in biota, of $0.09 \mathrm{mg} \mathrm{kg}^{-1}$ wet weight, indicating exposure to this element from pesticides, herbicides, or mine wastes [21]. Regarding $\mathrm{Pb}$, there is no toxic threshold established for this metal, and, thus, any lead concentration in the body is considered harmful [22]. Thus, levels detected in bile indicated at least some exposure to this metal in the environment, which may lead to deleterious effects.

$\mathrm{Hg}$ concentrations as low as $0.008 \mathrm{mg} \mathrm{kg}^{-1}$ wet weight in muscle are enough to affect biochemistry (for example, nervous system enzymatic activity), as well as gene expression, and thresholds for effects on reproduction, histology, and growth have been reported as approximately $0.135 \mathrm{mg} \mathrm{kg}^{-1}$ wet weight in muscle [23]. Thus, in the present study, $\mathrm{Hg}$ concentrations may pose a threat to the analyzed fish species, since both liver and bile metal concentrations were slightly higher than these thresholds.
With regard to $\mathrm{Cd}$, acute lethal effects for marine organisms have been noted at concentrations of approximately $4.8 \mathrm{mg} \mathrm{kg}^{-1}$ [24]. Thus, the values observed in the present study do not indicate concern related to exposure to this metal, as both liver and bile concentrations were orders of magnitude lower than this toxicity threshold.

Tissue levels above $1.2 \mathrm{mg} \mathrm{kg}^{-1}$ total $\mathrm{Cr}$ dry weight should be viewed as presumptive evidence of $\mathrm{Cr}$ contamination [25], which, in the present study, does not seem to be the case, as concentrations observed in both liver and bile were much lower than this limit.

Regarding $\mathrm{Al}, \mathrm{Ni}, \mathrm{Cu}, \mathrm{Fe}, \mathrm{Zn}$ and $\mathrm{Fe}$, the literature is extremely conflicting, and most reports generally state in many different ways that "these elements are essential but may become toxic at higher concentrations" (Hauser-Davis, Pers. Comm). Thus, no concrete comparisons regarding fish toxicity could be conducted with the values observed in the present study.

\subsection{Statistical correlations between MT and metals and trace-elements in G. brasiliensis bile and liver}

The significant $(\mathrm{p}<0.05)$ Pearson correlations observed between MT and metals and trace-elements in liver and bile are displayed in Table 3.

Table 3

Significant Pearson correlations between MT and metals and trace-elements in G. brasiliensis bile and liver from the Rodrigo de Freitas Lagoon, Rio de Janeiro, Brazil ( $\mathrm{n}=17)$.

\begin{tabular}{lll}
\hline Matrix & Relationship & Strength of the association \\
\hline Bile & MT x Fe & $\mathrm{r}=0.97$ \\
Liver x bile & MT (l) x Cu (b) & $r=0.93$ \\
& MT (l) x Zn (b) & $r=0.98$ \\
\hline
\end{tabular}

All significant correlations were very strong, observed in bile or between liver and bile. No associations were found for liver. Removal by the biliary route seem to be very efficient for Fe MT-detoxification, while in liver, $\mathrm{Cu}$ and $\mathrm{Zn}$ seem to be similarly bound to MT, noted by similar associations strengths, as expected, since both elements bind easily to MT for organism homeostasis [26].

The correlations between liver and/or bile MT and/or metals and trace-elements indicate an interesting link between these variables. On hypothesis to explain these correlation would be that free liver MT, excreted alongside excess bile, may be able to also bind to metals and trace-elements present in stored gallbladder bile. In fish, as in higher vertebrates, bile is produced continuously by the liver to aid in digestion, and the excess is stored and concentrated in the gallbladder by continuous water extraction, until the next feeding episode, where bile is then diluted and released into the small intestine [17]. As in the present study the bile ducts were carefully removed, it is improbable that any MT present in biliary fluid would be present in the liver samples. Thus, the significant, positive, strong and direct correlations observed between hepatic MT and $\mathrm{Cu}$ and $\mathrm{Zn}$ in bile indicate that these elements present in bile already removed by the liver for excretion may also continuously stimulate MT synthesis in liver, perhaps due to direct contact of this fluid with the liver through the biliary ducts.

\subsection{Statistical correlations between metal pairs in $G$. brasiliensis bile and} liver

In the present study, several positive strongstrong and very correlations were observed between elemental pairs in both bile and liver, as well as between elements in each of these organs (Table 4).

Organisms are exposed to environmental contaminants mostly encountered as mixtures [27] but, unfortunately, water quality criteria, toxicity assays and reference guidelines are usually established by 
Table 4

Significant correlations between elements involved in homeostasis and biological functions and between essential and toxic elements in G. brasiliensis from the Rodrigo de Freitas Lagoon, Rio de Janeiro, Brazil. (l) - liver; (b) bile.

\begin{tabular}{|c|c|c|}
\hline \multicolumn{3}{|c|}{$\begin{array}{l}\text { Significant relationships between elements involved in homeostasis and biological } \\
\text { functions }\end{array}$} \\
\hline Matrix & Relationship & Strength of the association \\
\hline \multirow[t]{4}{*}{ Liver } & $\mathrm{Se} \times \mathrm{Cu}$ & $r=0.92$ \\
\hline & $\mathrm{Co} \times \mathrm{Cr}$ & $\mathrm{r}=0.99$ \\
\hline & $\mathrm{Zn} \times \mathrm{Cr}$ & $\mathrm{r}=0.89$ \\
\hline & $\mathrm{Cu} \times \mathrm{Se}$ & $\mathrm{r}=0.92$ \\
\hline \multirow[t]{2}{*}{ Liver $\mathrm{x}$ bile } & $\mathrm{Ni}(\mathrm{l}) \times \mathrm{Fe}(\mathrm{b})$ & $\mathrm{r}=0.93$ \\
\hline & Ni (l) x Zn (b) & $\mathrm{r}=0.95$ \\
\hline \multicolumn{3}{|c|}{ Significant relationships between essential and toxic elements } \\
\hline Matrix & Relationship & Strength of the association \\
\hline \multirow[t]{4}{*}{ Liver } & $\mathrm{Fe} \times \mathrm{Al}$ & $\mathrm{r}=0.91$ \\
\hline & Co x Al & $\mathrm{r}=0.86$ \\
\hline & Se $\mathrm{x} \mathrm{Al}$ & $\mathrm{r}=0.93$ \\
\hline & $\mathrm{Cu} \times \mathrm{As}$ & $\mathrm{r}=0.99$ \\
\hline \multirow[t]{9}{*}{ Liver $\mathrm{x}$ bile } & $\mathrm{Cu}(\mathrm{l}) \times \mathrm{Cd}(\mathrm{b})$ & $\mathrm{r}=0.88$ \\
\hline & $\mathrm{Cr}(\mathrm{b}) \mathrm{x} \mathrm{Cd}(\mathrm{l})$ & $r=0.95$ \\
\hline & $\mathrm{Cu}(\mathrm{b}) \times \mathrm{Cd}(\mathrm{l})$ & $\mathrm{r}=0.93$ \\
\hline & $\mathrm{Fe}(\mathrm{b}) \mathrm{x} \mathrm{V}(\mathrm{l})$ & $r=0.89$ \\
\hline & $\mathrm{Zn}(\mathrm{l}) \times \mathrm{Hg}(\mathrm{b})$ & $r=0.95$ \\
\hline & Se (l) x Cd (b) & $\mathrm{r}=0.94$ \\
\hline & $\mathrm{Fe}(\mathrm{b}) \times \mathrm{Hg}$ (l) & $r=0.90$ \\
\hline & Co (b) x Hg (l) & $r=0.94$ \\
\hline & Co (l) x Pb (b) & $r=0.90$ \\
\hline
\end{tabular}

considering acute and chronic bioassays of individual chemicals only $[28,29]$. Co-solutes, however, may induce either synergistic (increased) or antagonistic (decreased) effects, as well as additive (independent) behavior [7]. Interactions between metals and trace-elements are related to their competitive uptake from the environment and different distribution patterns in fish tissues, and recent studies have suggested that interactive effects between metals and trace-elements must be considered in order to improve environmental monitoring and risk assessment efforts $[8,30,31]$ and that investigations of correlations between metals and trace-elements, both between those involved in homeostasis and biological functions and between essential and toxic elements, are paramount.

Metals and trace-elements enter the organisms via common routes and interact with each other affecting uptake, bioaccumulation and toxicity. The type of interaction depends on which elements are involved, their external concentration, bioavailability and exposure scenario, length of exposure, the studied species and the examined organs [8]. Statistical correlations between pairs of elements have been suggested as indicative of common sources of exposure, storage pathways or detoxification processes [32,33]. In the present study, all associations were positive and either strong or very strong, both between elements involved in homeostasis and biological functions and between essential and toxic elements.

Both positive and negative correlations between a specific element and different tissue types have been observed previously in fish [34], and seemingly indicate movement of elements between tissue. Thus, the positive correlations observed between elements in liver $\mathrm{x}$ bile (both between essential and essential and toxic elements) indicate excretion from the liver into the increasingly concentrated gallbladder bile, for subsequent excretion.

\subsection{Molar ratios for essential and toxic elemental pairs presenting statistically significant correlations in G. brasiliensis bile and liver}

Regarding the associations observed between essential and toxic elements, protection by essential elements against deleterious effects of toxic elements is still not well investigated [35], and only some associations have been described in the literature in this context. To further discuss these effects, the molar ratios for the significant associations between essential and toxic elements were calculated (Table 5).

The molar ratio calculations indicate protective effects against several toxic elements, with essential to toxic element molar ratios higher than 1 [36] in liver and in liver $\mathrm{x}$ bile, described in the next sections.

\subsubsection{Protective effect against $C d$}

A protective effect was observed against Cd present in both bile and liver. For $\mathrm{Cd}$ in bile, this was demonstrated by $\mathrm{Cu}: \mathrm{Cd}$ and Se:Cd molar ratios of 21:1 and 9:1, respectively, while for Cd in liver, a Cr:Cd ratio of 24:1 and a Cu:Cd of 3635:1 also indicated protective effects against $\mathrm{Cd}$ deleterious effects.

Cd bioavailability is very high; hence, it tends to bioaccumulate throughout the trophic food web [37]. Several different routes for Cd toxicity have been reported, and the basic underlying mechanisms are oxidative stress caused by $\mathrm{Cd}$ exposure $[38,39]$ and interactions between Cd and essential metals, mainly zinc, iron, calcium, and copper, by interfering with $\mathrm{Zn}$ metabolism and competing for gastrointestinal Zn absorption, decreasing $\mathrm{Fe}$ absorption and metabolism, possibly binding to ferritin and transferrin, decreasing intestinal Ca transport and interfering with $\mathrm{Cu}$ metabolism, possibly by decreasing $\mathrm{Cu}$ absorption [40-42]. Cd initselfi does not directly generate reactive oxygen species, but may alter intracellular reduced glutathione (GSH) levels, inducing MT expression in liver [43].

Se has been previously reported as exhibiting a protective effect against $\mathrm{Cd}$ exposure in aquatic organisms. For example, female zebrafish exposed to $0.4 \mathrm{mg} \mathrm{L}^{-1} \mathrm{Cd}$ in water and supplemented Se at $2 \mathrm{mg}$

Table 5

Molar ratios between essential and toxic elements in G. brasiliensis from the Rodrigo de Freitas Lagoon, Rio de Janeiro, Brazil.

\begin{tabular}{|c|c|c|c|}
\hline Matrix & Elements & Molar ratio & Probable effect \\
\hline \multirow[t]{4}{*}{ Liver } & $\mathrm{Fe} \times \mathrm{Al}$ & $115: 1$ & Protective effect against Al toxicity \\
\hline & $\mathrm{Co} \times \mathrm{Al}$ & $0.06: 1$ & No protective effect against $\mathrm{Al}$ toxicity \\
\hline & Se $x \mathrm{Al}$ & $0.80: 1$ & No protective effect against $\mathrm{Al}$ toxicity \\
\hline & $\mathrm{Cu} \times \mathrm{As}$ & $27: 1$ & Protective effect against As toxicity \\
\hline \multirow[t]{9}{*}{ Liver $x$ bile } & $\mathrm{Cu}(\mathrm{l}) \times \mathrm{Cd}(\mathrm{b})$ & $24: 1$ & Protective effect against Cd toxicity \\
\hline & $\mathrm{Cr}(\mathrm{b}) \times \mathrm{Cd}(\mathrm{l})$ & $24: 1$ & Protective effect against Cd toxicity \\
\hline & $\mathrm{Cu}(\mathrm{b}) \times \mathrm{Cd}(\mathrm{l})$ & $3635: 1$ & Protective effect against Cd toxicity \\
\hline & $\mathrm{Fe}(\mathrm{b}) \times \mathrm{V}(\mathrm{l})$ & $17: 1$ & Protective effect against $\mathrm{V}$ toxicity \\
\hline & $\mathrm{Zn}(\mathrm{l}) \times \mathrm{Hg}(\mathrm{b})$ & 7497:1 & Protective effect against $\mathrm{V}$ toxicity \\
\hline & Se (l) x Cd (b) & $9: 1$ & Protective effect against Cd toxicity \\
\hline & $\mathrm{Fe}(\mathrm{b}) \times \mathrm{Hg}(\mathrm{l})$ & 1921:1 & Protective effect against $\mathrm{Hg}$ toxicity \\
\hline & Co (b) $x \mathrm{Hg}(\mathrm{l})$ & $58: 1$ & Protective effect against $\mathrm{Hg}$ toxicity \\
\hline & $\mathrm{Co}(\mathrm{l}) \times \mathrm{Pb}(\mathrm{b})$ & $1.3: 1$ & Slight protective effect against $\mathrm{Pb}$ toxicity \\
\hline
\end{tabular}


$\mathrm{kg}^{-1}$ for 21 days via diet, displayed reversed Cd-induced toxicity in liver and ovaries, suggesting that the protective mechanism against Cdinduced oxidative stress is dependent on the correction of protein biological activities [44]. This has been confirmed in rats, where Se supplementation decreased Cd-induced nephrotoxicity and hepatotoxicity alterations [45], while also decreasing Cd-induced oxidative stress in rat liver and kidneys [46].

The protective effect of $\mathrm{Cu}$ against $\mathrm{Cd}$ has been demonstrated in several organisms, and the mechanism seems to be via antioxidant effects of ceruloplasmin, a Cu-carrier in plasma that acts as an antioxidant [47] and has been shown to be upregulated in fish serum in the presence of copper [48], as well as the homeostasis and antioxidant effects of MT, also upregulated and increasing protection against Cd toxicity in the presence of this essential element [49].

Concerning Cr, no protective effects of this elements concerning $\mathrm{Cd}$ toxicity were found in the literature, indicating further research is necessary in this regard.

\subsubsection{Protective effect against $\mathrm{Hg}$}

Regarding $\mathrm{Hg}$, a $\mathrm{Zn}: \mathrm{Hg}$ molar ratio of 7497:1 was observed for $\mathrm{Hg}$ in bile, indicating protective $\mathrm{Zn}$ effects in liver, while for $\mathrm{Hg}$ in liver protective effects were observed by a $\mathrm{Cu}: \mathrm{Hg}$ ratio of 1599:1, a Fe:Hg ratio of 1921:1 and a Co: $\mathrm{Hg}$ ratio of 58:1, with $\mathrm{Cu}, \mathrm{Fe}$ and $\mathrm{Co}$ in bile.

$\mathrm{Hg}$ is considered the most toxic element in the environment, particularly known to bioaccumulate throughout the trophic web [50]. Exposure to this metal can damage to the nervous system and kidneys [51], and, when in the form of organic mercury, it easily permeates across biomembranes and, as a lipophilic compound, accumulates in most species of fatty fish and in the liver of lean fish [52]. Regarding protective effects of essential elements against this toxic metal, certain relationships have been described in the literature, some more studied than others.

Fe has been shown to exert a protective effect against $\mathrm{Hg}$ toxicity, although only scarce studies are available in this regard and, to the best of our knowledge, only regarding rats [53-56]. Thus, further investigations in environmentally exposed organisms, especially fish, regarding this association are of interest.

Concerning Zn-Hg antagonism, Zn seems to have a significant impact on $\mathrm{Hg}$ distribution, [57], while the toxic effects of $\mathrm{Hg}$ have been shown to be exacerbated in Zn-deficient animals [58]. As discussed previously, increases in Zn levels induce MT synthesis. This occurs because the zincdependent metal-responsive transcription factor 1 (MTF-1) plays a role in activating MT transcription. In fact, it has been demonstrated that $\mathrm{Hg}$ is capable of displacing Zn to form the more stable Hg-MT complex, activating the synthesis of more MT and, in turn, increasing detoxification efficiency [59-61]. However, not many studies are available in this regard in the literature. Most have been, again, conducted with rats, and demonstrate different mechanisms of action regarding Zn protective effects. For example, in one of study, rats were exposed to $\mathrm{Zn}$ and $\mathrm{Hg}$ and kidneys were examined at 2, 6, and $12 \mathrm{~h}$ after treatment. Increases in GSH levels were observed, apparently related to the activation of some GSH-associated enzymes. The authors indicate that the response of the protective function involving GSH and GSH-associated enzymes depended on the magnitude of $\mathrm{Hg}$ toxicity but appeared to be independent of the $\mathrm{Zn}$ dosage. Thus, the data suggested that increased GSH levels in kidneys resulting from the activation of GSH-associated enzymes seems to play a role in the protective effect of $\mathrm{Zn}$ against $\mathrm{Hg}$ toxicity [62]. In another study, female rats exposed to $\mathrm{Hg}$ were subcutaneously injected with $\mathrm{Zn} 12$ or $48 \mathrm{~h}$ after $\mathrm{Hg}$ exposure, and the results indicate that $\mathrm{Zn}$ pretreatment prevented renal weight increase, partly prevented decreases in body weight gain and increases in creatinine levels, in addition to totally preventing renal $\delta$-aminolevulinic acid dehydratase inhibition, demonstrating different $\mathrm{Hg}$ effects and $\mathrm{Zn}$ protection mechanisms [63]. In the few studies conducted with fish, the authors do not propose a mechanistic pathway, but indicate that decreases in glucose and protein levels were observed in the intestine of catfish $H$. fossilis, as well as increases in alkaline phosphatase during $\mathrm{Hg}$ treatment for 30 days, which recovered to basal levels after $\mathrm{Zn}$ exposure, again suggesting a protective role of $\mathrm{Zn}$ against $\mathrm{Hg}$ toxicity [64].

Regarding the $\mathrm{Co}: \mathrm{Hg}$ association, no reports are available in the literature citing that $\mathrm{Co}$ is effective in protecting against $\mathrm{Hg}$ toxic effects. However, Co has been shown to act synergistically in the presence of Se [65], perhaps showing the same protective effects against $\mathrm{Hg}$ due to the presence of Se. In addition, Co, alongside Se and Zn, has also been implicated in the induction of MT synthesis [66], which may also justify protective effects indicated by the high $\mathrm{Co}: \mathrm{Hg}$ ratio observed in $G$. brasiliensis.

Until recently, few papers reporting molar ratios are available, mainly $\mathrm{Se}: \mathrm{Hg}$, and even less studies with regard to the associations between this toxic element and other metals are found [67]. The presence of the significant associations between several metals, as well as molar ratios indicative of protective effects against $\mathrm{Hg}$, demonstrate the need for further research in this regard, since most of the research conducted to date focuses mainly on the relationship between Se and $\mathrm{Hg}$. In fact, governments have even acted on the data with regard to the antagonist effects of Se on $\mathrm{Hg}$, and in some Nordic countries, such as Sweden, entire lakes have been treated with Se to combat Hg toxicity [68]. Thus, further investigation of other metal and trace-element associations against the toxic effects of $\mathrm{Hg}$ may also aid in decisionmaking processes regarding environmental contamination scenarios.

\subsubsection{Protective effect against As}

A Cu:As molar ratio of 27:1 was observed in liver, indicative of protective effects against As toxicity. As is prominently toxic and carcinogenic, and cells accumulate As by using an active transport system normally used in phosphate transport [21]. This element affects primarily the sulphydryl group of cells causing malfunctioning of critical cellular pathways, such as cell respiration, cell enzymes and mitosis $[37,69,70]$, in addition to producing excess reactive organic species, contributing to oxidative stress [71]. Even though As is mainly found in its less toxic organic forms in aqiatic organisms in general, since inorganic As species are metabolized by methylation into organic forms and excreted much faster than inorganic species [72,73], liver has been shown as a major target of As toxicity [70]. For example, exposure to $\mathrm{NaAsO}_{2}$ was found to cause liver chromosomal DNA fragmentation in Channa punctatus in hepatocytes [70].

Regarding Cu-As interactions, antagonist effects have been reported between these elements, although reports are scarce in this regard, have been mainly conducted with rats and deal only with the effects of As exposure on $\mathrm{Cu}$ levels. For example, one study reported decreases in $\mathrm{Cu}$ levels in liver after exposure to As, in a dose-dependent manner, while exacerbating $\mathrm{Cu}$ deficiency in other tissues [74]. No reports citing protective effects of $\mathrm{Cu}$ regarding As toxicity, however, are available in the literature, and further studies are of importance in this regard, since a protective relationship might be in effect.

\subsubsection{Protective effect against $\mathrm{Al}$}

In liver, a Fe:Al molar ratio of 115:1, was observed indicating protective effects against $\mathrm{Al}$, while $\mathrm{Co}$ and $\mathrm{Al}$ ratios of 0.06:1 and 0.80:1 were noted, indicating no protective effects against Al toxicity.

$\mathrm{Al}$ as the free metal cation is highly biologically reactive, and biologically available $\mathrm{Al}$ is known as non-essential and essentially toxic [75]. In addition, no homeostasis mechanisms concerning $\mathrm{Al}$ are available, and no element-specific biological responses to its presence and its availability are known [75]. Some studies indicate decreased bone mineralization after $\mathrm{Al}$ exposure, due to alterations in $\mathrm{Ca}$ influx and efflux from bone cells [76]. In fish, $\mathrm{Al}$ is highly toxic in acid waters, with the gills as the main target, leading to a combination of ionoregulatory, osmoregulatory and respiratory dysfunctions [77]. Lowmolecular weight inorganic $\mathrm{Al}$ forms of are believed to be the most important $\mathrm{Al}$ species concerning fish toxicity [78].

$\mathrm{Fe}$ and $\mathrm{Al}$ share important biological pathways, and it has been 
reported that these elements display direct effects on both metabolisms $[79,80]$. Concerning the protective effect of Fe against $\mathrm{Al}$, Fe has been reported as interfering with $\mathrm{Al}$ absorption in humans, due to high serum ferritin levels [81], while experiments carried out in iron-depleted rats demonstrated significant increases in gastrointestinal $\mathrm{Al}$ absorption and brain Al content, while iron-overloaded animals seemed to display protection against $\mathrm{Al}$ accumulation, which was also observed in studies carried out with human epithelial intestinal and bone cells [79]. However, no literature on the protective effect of Fe against $\mathrm{Al}$ in fish was found.

\subsubsection{Protective effect against $V$}

A molar ratio for Fe: $\mathrm{V}$ of 17:1 was observed for $\mathrm{V}$ in liver, indicating protective effects against $\mathrm{V}$.

$\mathrm{V}$ is a redox-active metal, and, thus, may be involved in oxidative injury mechanisms. In certain conditions, it may enhance the generation of oxygen-derived reactive species and stimulate lipid peroxidation [82]. The most toxic form of $\mathrm{V}$ for mammals seems to be pentavalent vanadium (Roshchin, 1967). Although some accumulation of this element has been reported in rats (Shroeder \& Balassa, o1967), this metal

\subsubsection{Protective effect against $P b$}

A Co: $\mathrm{Pb}$ molar ratio of 1.3:1 was observed for $\mathrm{Pb}$ in bile and, seemingly indicating a certain amount of protective effects against $\mathrm{Pb}$, although this ratio was low compared to the other elements observed herein. Thus, the protective effect in this regard, if any, should be very slight. However, no literature records on a protective role in this regard were found. As Co is a redox-active element, it may play a role in dealing with the effects of $\mathrm{Pb}$ bonding to protein sulphydryl groups and glutathione depletion, as reported elsewhere [86], which may lead to increased reactive species in the cell, although further studies are necessary.

\subsection{PCA and cluster analysis}

The PCA (Fig. 3) distinctly separated the elements found in liver from those found in bile, comprising Factor 1, responsible for $44.87 \%$, and Factor 2, responsible for $22.59 \%$ of the total data variability. The former is more strongly correlated to variables $\mathrm{V}, \mathrm{Fe}, \mathrm{Cu}, \mathrm{Zn}, \mathrm{As}$, Se and MT, while the latter is more strongly correlated to $\mathrm{Cd}, \mathrm{Co}, \mathrm{Pb}$ and $\mathrm{Ni}$, confirming their importance with regard to separation between tissues.

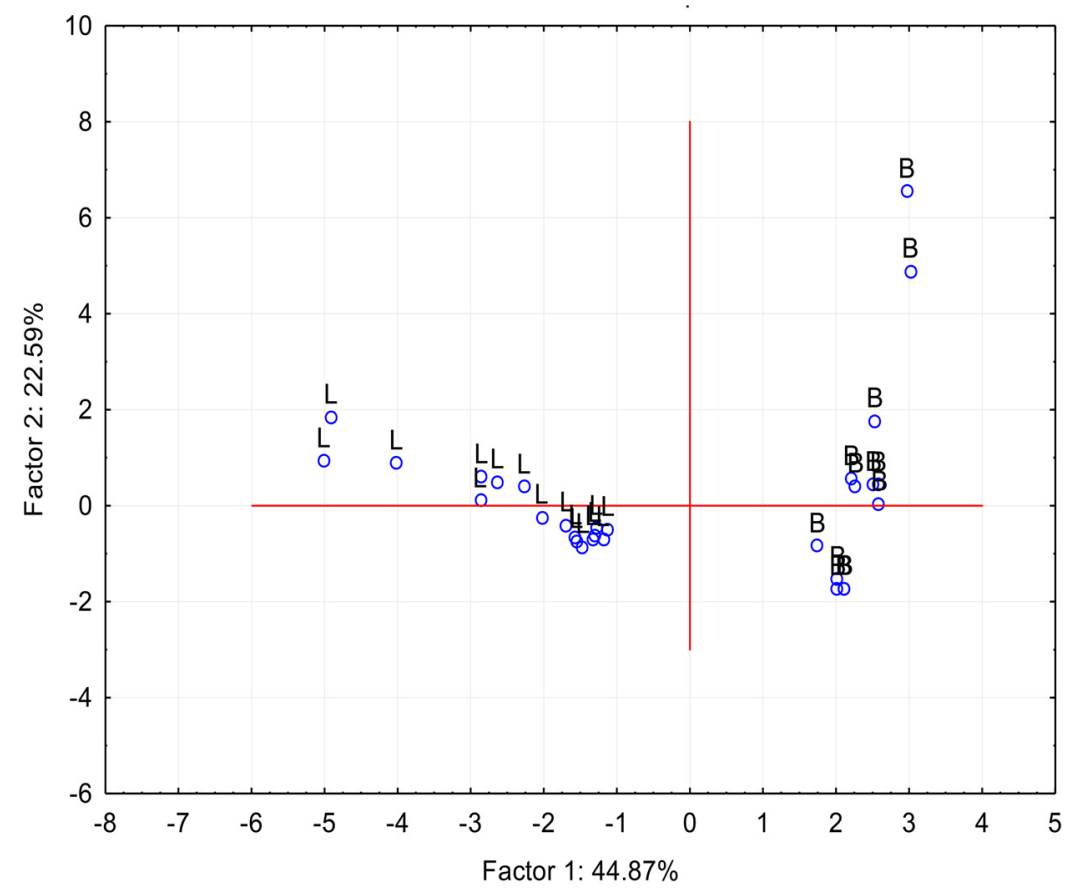

Fig. 3. PCA plot of G. brasiliensis liver and bile data. L-Liver; B - Bile.

is also excreted readily, mostly via urine (Dimond et al.,1963). Aquatic toxicity of this element to fish, however, has not been well characterized [83]. In the few studies observed in the literature, exposure to $\mathrm{V}$ was shown to decrease larvae growth and survival in adult American Flagfish (Jordanella floridae) [84], while V toxicity to Heteropneustes fossilis led to increased glucose values and decreased total protein content in liver, muscle and kidney [85]. However, again, no literature was found concerning the protective effect of Fe against $\mathrm{Al}$ toxicity in fish, thus, indicating that further studies are also required.
The cluster grouping further corroborated the PCA results, where $\mathrm{Pb}, \mathrm{Cd}$, Co and $\mathrm{Ni}$ were present in lower concentrations in liver, evidencing that data separation was due to the elements present in lower levels in each matrix. Thus, this further confirms the detoxification processes that occur between these tissues and the investigated elements, and data separation seems to be due to, in fact, the elements more efficiently detoxified from the liver, confirming the previous discussions conducted in this regard (Fig. 4). 


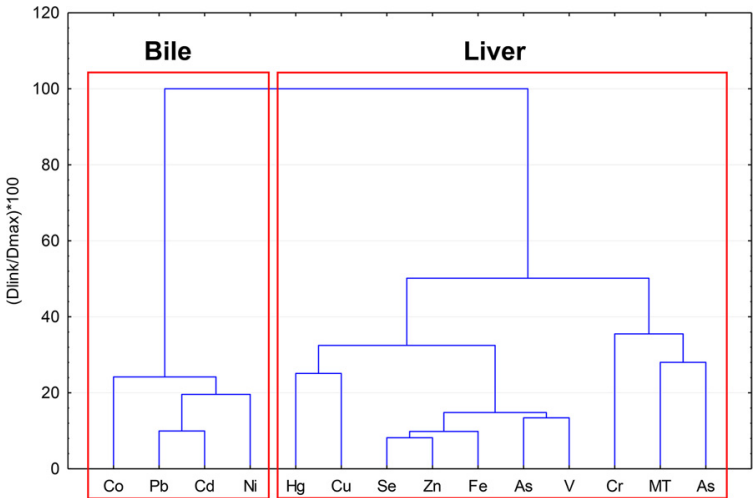

Fig. 4. Cluster analysis of $G$. brasiliensis liver and bile metal and MT data.

\section{Conclusions}

Metal and trace-element detoxifying routes in fish include the biliary and hepatic pathways. Taken together, the analysis of metals and trace-elements and MT levels in bile instead of liver is indeed viable to indicate the presence of these contaminants, in the environment, although some differences between liver and biliary metals and traceelements are expected.

In addition, molar ratio calculations demonstrated protective metal and trace-elements effects against $\mathrm{Al}, \mathrm{As}, \mathrm{Cd}, \mathrm{Hg}$ and $\mathrm{Pb}$ in both bile and liver, demonstrating inter-elemental relationships that seem to aid in protection against the effects of toxic elements. This includes some interrelationships that either have been scarcely reported, or even not at all, indicating the importance of these investigations regarding the elucidation of metal and trace-element detoxifying mechanisms. Moreover, the investigation of other metal associations against the deleterious effects of toxic elements may also aid in decision-making processes regarding environmental contamination scenarios.

\section{Conflict of interest}

The authors declare no conflict of interest.

\section{Acknowledgement}

The authors would like to thank Marcos Frejat for the impeccable artwork. This study was conducted at a time of great political and economic difficulties in Brazil. We hope things will change for the better soon.

\section{References}

[1] P. Censi, S.E. Spoto, F. Saiano, M. Sprovieri, S. Mazzola, G. Nardone, S.I. Di Geronimo, R. Punturo, D. Ottonello, Heavy metals in coastal water systems. A case study from the northwestern Gulf of ThailandAug, Chemosphere 64 (7) (2006) 1167-1176.

[2] C. Hogstrand, C. Haux, Binding and detoxification of heavy metals in lower vertebrates with reference to metallothionein, Comp. Biochem. Physiol. 100C (1991) 137-141.

[3] D.R. Livingstone, Biotechnology and pollution monitoring: use of molecular biomarkers in the aquatic environment, J. Chem. Technol. Biotechnol. 57 (3) (1993) $195-211$.

[4] M.V.R. Kumani, M. Hiramatsu, M. Ebadi, Free radical scavenging actions of metallothionein isoforms I and II, Free Radic. Res. 29 (2) (1998) 93-101.

[5] R.A. Hauser-Davis, R.A. Gonçalves, R.L. Ziolli, R.C. de Campos, A novel report of metallothioneins in fish bile: SDS-PAGE analysis, spectrophotometry quantification and metal speciation characterization by liquid chromatography coupled to ICP-MS, Aquat. Toxicol. 116-117 (2012) 54-60.

[6] R.A. Hauser-Davis, F.F. Bastos, T.F. Oliveira, R.L. Ziolli, R.C. de Campos, Fish bile as a biomarker for metal exposure, Mar. Pollut. Bull. 64 (8) (2012) 1589-1595.

[7] R. Altenburger, M. Nendza, G. Schuurmann, Mixture toxicity and its modeling by quantitative structure-activity relationships, Environ. Toxicol. Chem. 22 (2003)
1900-1915.

[8] W.P. Norwood, U. Borgmann, D.G. Dixon, A. Wallace, Effects of metal mixtures on aquatic biota: a review of observations and methods, Hum. Ecol. Risk Assess. 9 (2003) 795-811.

[9] E.M. Fonseca, J.A. Baptista Neto, M.A. Fernandez, J. Mcalister, B. Smith, Geochemical behavior of heavy metals in differents environments in Rodrigo de Freitas lagoon - RJ/Brazil, Annais da Academia Brasileira de Ciências 83 (2) (2011) 457-469.

[10] C.G. Vilela, D.S. Batista, J.A. Baptista Neto, R.O. Ghiselli Jr., Benthic foraminifera distribution in a tourist lagoon in Rio de Janeiro, Brazil: a response to anthropogenic impacts, Mar. Pollut. Bull. 62 (10) (2011) 2055-2074.

[11] RJ, http://www.creci-rj.gov.br, (2016).

[12] S.L. Shah, A. Attinag, Effects of heavy metal accumulation on the 96-h LC50 values in Tench (Tinca Tinca L.) 1758, Turk. J. Vet. Anim. Sci. 29 (2005) 139-144.

[13] M. Erk, D. Ivankovi, B. Raspor, J. Pavicic, Evaluation of different purification procedures for the electrochemical quantification of mussel metallothioneins, Talanta 57 (2002) 1211-1218.

[14] A. Viarengo, E. Ponzano, F. Dondero, R. Fabbri, A simple spectrophotometric method for metallothionein evaluation in marine organisms: an application to Mediterranean and Antarctic molluscs, Mar. Environ. Res. 44 (1) (1997) 69-84.

[15] G.L. Ellman, Tissue sulfhydryl groups, Arch. Biochem. Biophys. 82 (1) (1959) $70-77$.

[16] J.H.R. Kagi, Overview of metallothionein, in: J.F. Rierdan, B.L. Vallee (Eds.), Methods of Enzymology: Metallobiochemistry: Metallothionein and Related Molecules, Acadmeic Press, San Diego, 1991, pp. 613-626.

[17] L.S. Smith, Digestion in teleost fishes, aquaculture development and coordination programme, Fish Feed Technology, FAO, Rome, 1980.

[18] NRCC, Effects of Arsenic in the Canadian Environment, NRCC, 1978, pp. 1-249.

[19] P. Jankong, C. Chalhoub, N. Kienzi, W. Goessler, K.A. Francesconi, P. Visoottiviseth, Arsenic accumulation and speciation in freshwater fish living in arsenic-contaminated waters, Environ. Chem. 4 (2007) 11-17.

[20] D.A. Lemly, Guidelines for evaluating selenium data from aquatic monitoring and assessment studies, Environ. Monit. Assess. 28 (1993) 83-100.

[21] R. Eisler, Arsenic Hazards to Fish, Wildlife and Invertebrates: a Synoptic Review, Biological Report 85 (1.12) - Contaminant Hazard Reviews, US. Department of the Interior, Fish and Wildlife Service, 1988 p. 92.

[22] E.K. Silberlgeld, Testimony of Professor Ellen K Silbergeld. Bloomberg School of Public Health, Johns Hopkins University, Baltimore, MD. Lead Contamination in the District of Columbia Water Supply. Oversight Committee on Government Reform, House of Representatives, U.S. Congress, 2004.

[23] M.B. Sandheinrich, J.G. Wiener, Methylmercury in freshwater fish: recent advances in assessing toxicity of environmentally relevant exposures, in: W.N. Beyer, J.P. Meador (Eds.), Environmental Contaminants in Biota: Interpreting Tissue Concentrations, CRC Press, Boca Raton, FL, 2011, pp. 169-192.

[24] WHO, Environmental Health Criteria No 135- Cadmium - Environmental Aspects, World Health Organisation, Geneva, 1992.

[25] R. Eisler, Chromium Hazards to Fish, Wildlife and Invertebrates: a Synoptic Review, Biological Report 85 (1.12) - Contaminant Hazard Reviews, US. Department of the Interior, Fish and Wildlife Service, 1986 p. 38.

[26] W.-C. Wang, H. Mao, D.-D. Ma, W.-X. Yang, Characteristics, functions, and applications of metallothionein in aquatic vertebrates, Front. Mar. Sci. (2014).

[27] K.A. Jeys, R.F. Shore, M.G. Pereira, K.C. Jones, F.L. Martin, Risk assessment of environmental mixture effects, RSC Adv. 6 (2016) 47844-47857.

[28] A.A. Otitolojou, Relevance of joint action toicity evaluations in setting realistic environmental safe limits of heavy metals, J. Environ. Manage. 67 (2002) 121-128.

[29] J.R. Shaw, T.D. Depnsey, C.Y. Chen, J.W. Hamilton, C.L. Folt, Comparative toxicity of cadmium, zinc and mixture of cadmium and zinc to daphnids, Environ. Toxicol. Chem. 25s (2006) 182-189.

[30] S.A. Peterson, N.V.C. Ralston, D.V. Peck, J. Van Sickle, J.D. Robertson, V.L. Spate, J.S. Morris, How might selenium moderate the toxic effects of mercury in stream fish of the western US? Environ. Sci. Technol. 43 (10) (2009) 3919-3925.

[31] D.Y. Yang, X. Ye, Y.W. Chen, N. Belzile, Inverse relationships between selenium and mercury in tissues of young walleye (Stizosedion vitreum) from Canadian boreal lakes, Sci. Total Environ. 408 (7) (2009) 1676-1683.

[32] A.R. Ribeiro, C. Eira, J. Torres, P. Mendes, J. Miquel, A.M.V.M. Soares, J. Vingada, Toxic element concentrations in the razorbill Alca torda (Charadriiformes, Alcidae) in Portugal, Arch. Environ. Contam. Toxicol. 56 (2009) 588-595.

[33] S. Jerez, M. Motas, J. Benzal, J. Diaz, A. Barbosa, Monitoring trace elements in Antarctic penguin chicks from South Shetland Islands, Antarctica, Mar. Pollut. Bull. 69 (2013) 67-75.

[34] C.P. Erasmus, The Concentration of Ten Metals in the Tissues of Shark Species Squalus megalops and Mustelus mustelus (Chondrichthyes) Occuring Along the Southeastern Coast of South Africa, University of Port Elizabeth, 2004.

[35] A.R. Volpe, P. Cesare, P. Aimola, M. Boscolo, G. Valle, M. Carmignani, Zinc opposes genotoxicity of cadmium and vanadium but not of lead, J. Biol. Regul. Homeost. Agents 25 (4) (2011) 589-601.

[36] N.V.C. Ralston, J. Lloyd Blackwell, L.J. Raymond, Importance of molar ratios in selenium-dependent protection against methylmercury toxicity, Biol. Trace Elem. Res. 119 (2007) 255-268.

[37] M. Jaishankar, T. Tseten, N. Anbalagan, B.B. Mathew, K.N. Beeregowda, Toxicity, mechanism and health effects of some heavy metals, Interdiscip. Toxicol. 7 (2) (2014) 60-72.

[38] P. Morcillo, M.A. Esteban, A. Cuesta, Heavy metals produce toxicity, oxidative stress and apoptosis in the marine teleost fish SAF-1 cell line, Chemosphere 144 (2016) 225-233.

[39] J.A. Almeida, R.E. Barreto, E.L.B. Novelli, F.J. Castro, S. Moron, Oxidative stress 
biomarkers and aggressive behavior in fish exposed to aquatic cadmium contamination, Neotropical. Ichtyol. 7 (1) (2009) 103-108.

[40] M.A. López, F.M. Prieto, M. Miranda, C. Castillo, J. Hernández, J. Luis Benedito, Interactions between toxic (As, $\mathrm{Cd}, \mathrm{Hg}$ and $\mathrm{Pb}$ ) and nutritional essential (Ca, $\mathrm{Co}, \mathrm{Cr}$, $\mathrm{Cu}, \mathrm{Fe}, \mathrm{Mn}, \mathrm{Mo}, \mathrm{Ni}, \mathrm{Se}, \mathrm{Zn}$ ) elements in the tissues of cattle from NW Spain, Biometals 17 (4) (2004) 389-397.

[41] M.A. Peraza, F. Ayala-Fierro, D.S. Barber, E. Casarez, L.T. Rael, Effects of micronutrients on metal toxicity, Environ. Health Perspect. 106 (1998) 203-216.

[42] R.A. Goyer, Toxic and essential metal interactions, Annu. Rev. Nutr. 17 (1997) $37-50$.

[43] M. Sevcikova, H. Mordra, A. Slaninova, Z. Svobodova, Metals as a cause of oxidative stress in fish: a review, Vet. Med. (Praha) 56 (2011) 537-546.

[44] M. Banni, L. Chouchene, K. Said, A. Kerkeni, I. Messaoudi, Mechanisms underlying the protective effect of zinc and selenium against cadmium-induced oxidative stress in zebrafish Danio rerio, Biometals 24 (6) (2011) 981-992.

[45] S.J.S. Flora, J.R. Behari, M. Ashquin, S.K. Tandon, Time-dependent protective effect of selenium against cadmium-induced nephrotoxicity and hepatotoxicity, Chem. Biol. Interact. 2 (3) (1982) 345-351.

[46] B.I. Ognjanovic, S.D. Markovic, R.V. Pavlovic, R.V. Zikic, A.S. Stajn, Z.S. Saicic, Effect of chronic cadmium exposure on antioxidant defense system in some tissues of rats: protective effect of selenium, Life Sci. Adv. Plant Physiol. 57 (2008) 403-411.

[47] S.C. Luza, H.C. Speisky, Liver copper storage and transport during development: implications for cytotoxicity, Am. J. Clin. Nutr. 63 (1996) 812-820.

[48] S. Parvez, I. Sayeed, S. Pandey, A. Ahmad, B. Bin-Hafeez, R. Haque, I. Ahmad, S. Raisuddin, Modulatory effect of copper on non-enzymatic antioxidants in freshwater fish Channa punctatus (Bloch.), Biol. Trace Elem. Res. 93 (2003) 237-248.

[49] G. Roesijadi, Metallothionein and its role in toxic metal regulation, Comp. Biochem. Physiol. C 3 (1996) 117-123.

[50] C.Y. Chen, M. Dionne, B.M. Mayes, D.M. Ward, S. Sturup, B.P. Jackson, Mercury bioavailability and bioaccumulation in estuarine food webs in the Gulf of Maine, Environ. Sci. Technol. 43 (6) (2009) 1804-1810.

[51] D.H. Adams, C. Sonne, N. Basu, R. Dietz, D.-H. Nam, P.S. Leifsson, A.L. Jensen, Mercury contamination in spotted seatrout, Cynoscion nebulosus: an assessment of liver, kidney, blood, and nervous system health, Sci. Total Environ. 408 (2010) 5808-5816.

[52] C. Reilly, Pollutants in food - metals and metalloids, in: P. Szefer, J.O. Nriagu (Eds.), Mineral Components in Foods, Taylor \& Francis Group, Boca Raton, FL, 2007, pp. 363-388.

[53] A.S. Saljooghi, F.D. Mendi, The effect of mercury in iron metabolism in rats, J. Clin. Toxicol. 3 (2013) 1-5.

[54] A. Grosicki, B. Kowalski, J. Rachubik, Absorption and distribution of inorganic mercury in rats fed a copper-supplemented diet, Bull. Vet. Inst. Pulawy 41 (1997) $149-156$.

[55] K. Kostial, I. Rabat, M. Blamusa, I. Simonovic, The effect of iron additive to milk on cadmium, mercury, and manganese absorption in rats, Environ. Res. 22 (1) (1980) 40-45.

[56] A. Grosicki, S. Kossakowski, Inorganic mercury absorption and distribution in rats treated with iron, Polish J. Environ. Stud. 4 (3) (1995) 2326.

[57] M.J. Małuszyński, A. Popenda, Interactions of mercury in the environment - Land reclamation, Ann. Warsaw Univ. Life Sci. 45 (2) (2013) 255-260.

[58] Committee on minerals and toxic substances in diets and Water for animals and board on agriculture and natural, Mercury, Miner. Toler. Anim. (2005) 248-258.

[59] E.G. Sørmo, T.M. Cieselski, I.B. Øverjordet, S. Lierhagen, G.S. Eggen, T. Berg, B.M. Jenssen, Selenium moderates mercury toxicity in free-ranging freshwater fish, Environ. Sci. Technol. 45 (2011) 6561-6566.

[60] I. Sabolic, D. Breljak, M. Skarica, M. Carol, H. Kramberger, Role of metallothionein in cadmium traffic and toxicity in kidneys and other mammalian organs, Biometals 23 (2010) 97-926.

[61] N. Sakulsak, metallothionein: an overview on its metal homeostatic regulation in mammals, Int. J. Morphol. 30 (3) (2012) 1007-1012.

[62] H. Fukino, M. Hirai, Y.M. Hsueh, S. Moriyasu, Y. Yamane, Mechanism of protection by zinc against mercuric chloride toxicity in rats: effects of zinc and mercury on glutathionine metabolism, J. Toxicol. Environ. Health 19 (1) (1986) 75-89.

[63] M. Mesquita, T.F. Pedroso, C.S. Oliveira, V.A. Oliveira, R.F. do Santos, C.A. Bizzi, M.E. Pereira, Effects of zinc against mercury toxicity in female rats 12 and 48 hours after $\mathrm{HgCl}_{2}$ exposure, EXCLI J. 15 (2016) 256-267.

[64] P. Sangeeta, J. Bhoraskar, S. Dubev, Protection by zinc against mercury toxicity in the intestine of a catfish-heteropneustes fossilis - a biochemical study, Environ. Conserv. J. 10 (3) (2009) 125-128.

[65] D.L. Watts, The nutritional relationships of selenium, J. Orthomol. Med. 9 (2) (1994) 111-117.

[66] Toxic metals, radionuclides and packaging, in: S.S. Deshpande (Ed.), Handbook of Food Toxicology, Marcel Dekker, Inc, 2002, pp. 783-812.

[67] J. Burger, M. Gochfeld, Selenium and mercury molar ratios in commercial fish from New Jersey and Illinois: variation within species and relevance to risk communication, Food Chem. Toxicol. 57 (2013) 235-245.

[68] K. Paulsson, K. Lundbergh, Treatment of mercury contaminated fish by selenium addition, Water Air Soil Pollut. 56 (1991) 833-841.

[69] G.M. Habib, Z. Shi, M.W. Lieberman, Glutathione protects cells against arseniteinduced toxicity, Free Radic. Biol. Med. 42 (2007) 191-201.

[70] S. Das, B. Unni, M. Bhattacharjee, S.B. Wann, P.G. Rao, Toxicological effects of arsenic exposure in a freshwater teleost fish, Channa punctatus, Afr. J. Biotechnol. 11 (19) (2012) 4447-4454.

[71] H. Shi, X. Shi, K.J. Liu, Oxidative mechanism of arsenic toxicity and carcinogenesis, Mol. Cell. Biochem. 255 (2004) 67-78.

[72] B.K. Mandal, K.T. Suzuki, Arsenic round the world: a review, Talanta 58 (1) (2002) 201-235.

[73] WHO, Arsenic, Fact Sheet $N^{\circ} 372$, (2012).

[74] E.O. Uthus, High dietary arsenic exacerbates copper deprivation in rats, J. Trace Elem. Exp. Med. 14 (2001) 43-55.

[75] C. Exley, The toxicity of aluminium in humans, Morphologie 100 (329) (2016) 51-55.

[76] J.B.C. Andia, Aluminium toxicity: its relationship with bone and iron metabolism, Nephrol. Dial. Transplant. 11 (1996) 69-73.

[77] C. Exley, J.S. Chappell, J.D. Birchall, A mechanism for acute aluminium toxicity in fish, J. Theor. Biol. 151 (3) (1991) 417-428.

[78] A.B.S. Polio, S.A. Oxnevad, K. Ostbye, R.A. Andersen, D.H. Oughton, L.A. Vsllestad, Survival of crucian carp, Carassius Carassius, exposed to a high lowmolecular weight inorganic aluminium challenge, Aquat. Sci. 57 (1995) 350-359.

[79] J.B. Cannata, I. Fernandez Soto, M.J. Fernandez Menendez, J.L. Fernandez Martin, S. McGregor, J.H. Brock, D. Halls, Role of iron metabolism in absorption and cellular uptake of aluminium, Kidney Int. 39 (1991) 799-803.

[80] J.B. Cannata, J.B. Diaz Lopez, Insights into complex aluminium and iron relationship, Nephrol. Dial. Transplant. 6 (1991) 605-607.

[81] J.B. Cannata, C. Suarez, M.V. Cuesta, R. Rodriguez Roza, M.T. Allende, J. Herrera, J. Perez Llanderal, Gastrointestinal aluminium absorption: is it modulated by the iron-absorptive mechanism? Proc. Eur. Dial. Transplant. Assoc. 21 (1984) 354-363.

[82] A. Ścibior, D. Gołębiowska, I. Niedźwiecka, Magnesium can protect against Vanadium-induced lipid peroxidation in the hepatic tissue, Oxid. Med. Cell. Longev. 2013 (2013).

[83] J.J. Gravenmier, D.W. Johnston, W.R. Arnold, Acute toxicity of vanadium to the threespine stickleback, Gasterosteus aculeatus, Environ. Toxicol. 20 (1) (2005) $18-22$.

[84] D.A. Holdway, J.B. Sprague, Chronic toxicity of vanadium to flagfish, Water Res. 13 (1979) 905-910.

[85] A. Bikkini, P. Nanda, Vanadium toxicity to fish Heteropneustes fossilis (Bloch), Int. J. Fish. Aquat. Stud. 4 (5) (2016) 316-317.

[86] K. Jomova, M. Valko, Advances in metal-induced oxidative stress and human disease, Toxicology 283 (2011) 65-87. 